\title{
Analisis Kesesuaian Kawasan Perairan untuk Ekowisata Diving di Pulau Soreh Kabupaten Bintan
}

\author{
Analysis of the Suitability of Water Areas for Diving Ecotourism in Soreh Island, Bintan Regency \\ M.Ramlan ${ }^{1)}$, Dedy Kurniawan ${ }^{1)^{*}}$, Susiana ${ }^{1)}$ \\ ${ }^{1}$ Program Studi Manajemen Sumberdaya Perairan, Fakultas IImu Kelautan dan \\ Perikanan,Universitas Maritim Raja Ali Haji, Tanjungpinang
}

Penulis korespondensi : Email : dedykurniawan@umrah.ac.id

(Diterima November 2020/ Disetujui April 2021)

\begin{abstract}
The purpose of this study was to see the ecological potential, community perception and participation as well as to analyze the suitability and carrying capacity of Soreh island waters for snorkeling and diving ecotourism. The research method used was a survey method with a purposive sampling technique that consisted of 2 stations and 4 observation points. Collecting coral data using the PIT (Point Intersept Transect) method, fish data using the UVC (Underwater Visual Census) method, data using a secchi disc, data current using a bottle filled with water and bound to a predetermined size, data using a pendulum or a weight with a rope size and social data by interview method. Based on observations of the potential for live coral cover of $1-70 \%$, the area preserving an area of $47.2-100 \%$, the number of sea coral species is 1-13 species, 4-14 fish species, $10.82-13.36 \mathrm{~cm} /$ second, depth of coral reef around 3.50-10 meters, accessibility as much as 1 aspect, and 1 species of dangerous biota. The suitability of snorkeling and diving tourism in the waters of Soreh island at each station and observation point is a suitable area for the development of snorkeling and diving ecotourism. The carrying capacity of coral reefs for the development of diving tourism in the waters of Soreh island at each station and point is suitable for developing diving tourism.
\end{abstract}

Keywords: Ecological potential, suitability and carrying capacity, diving, Soreh Island.

\section{ABSTRAK}

Tujuan penelitian ini adalah untuk mengetahui potensi ekologis serta analisis kesesuaian dan daya dukung kawasan perairan Pulau Soreh untuk ekowisata diving. Metode penelitian yang digunakan adalah metode survei dengan teknik pengambilan sampel secara purposive sampling yang terdiri dari 2 stasiun.Pengambilan data parameter lingkungan menggunakan metode yang umum digunakan seperti PIT (Point Intersept Transect), UVC (Under Visual Census) dan wawancara. Berdasarkan hasil pengamatan potensi tutupan karang hidup sebesar 1-70\%, kecerahan perairan memiliki kecerahan berkisar $47,2-100 \%$, jumlah jenis life form karang sebanyak 1-13 jenis, jenis ikan karang sekitar 4-14 jenis, kecepatan arus sebesar 10,82-13,36 cm/detik, kedalaman terumbu karang sekitar 3,50-10 meter, aksesibilitas sebanyak 1 aspek, dan biota berbahaya sebanyak 1 jenis. Kesesuaian wisata diving di Perairan P. Soreh pada setiap stasiun merupakan kawasan yang sesuai untuk dilakukan pengembangan ekowisata diving. Daya dukung terumbu karang untuk pengembangan ekowisata diving di Perairan P. Soreh pada setiap stasiun sesuai untuk dilakukan pengembangan wisata diving.

Kata Kunci: Potensi ekologis, kesesuaian dan daya dukung, diving, Pulau Soreh.

\section{PENDAHULUAN}

Kepulauan Riau merupakan salah satu provinsi yang ada di Indonesia, dengan ibu kota Tanjungpinang. Provinsi Kepulauan Riau merupakan Provinsi ke-32 yang terbentuk berdasarkan Undang-Undang Nomor 25 Tahun 2002, Provinsi Kepulauan Riau memiliki luas wilayah sebesar

To Cite this Paper: Ramlan, M., Kurniawan, D., Susiana. 2021. Analisis Kesesuaian Kawasan Perairan untuk Ekowisata Diving di Pulau Soreh, Kabupaten Bintan. Samakia: Jurnal IImu Perikanan, 12 (2) : 131-138

Journal Homepage: https://journal.ibrahimy.ac.id/index.php/JSAPI 
417.012,97 km² (BPS KEPRI 2015). Provinsi Kepulauan Riau memiliki potensi pulau-pulau kecil sebanyak 240 pulau-pulau kecil. Kawasan pulau-pulau kecil merupakan aset wisata bahari yang sangat besar yang didukung oleh potensi geologis dan karakteristik yang mempunyai hubungan sangat dekat dengan terumbu karang (coral reef), khususnya hard corals. Salah satu kabupaten yang ada di Provinsi Kepulauan Riau yaitu Kabupaten Bintan. Kabupaten Bintan merupakan salah satu kabupaten yang memiliki ekosistem terumbu karang seluas $17.394,83$ ha yang cocok untuk kegiatan ekowisata bahari (BPS KEPRI 2015).

Ekowisata bahari merupakan salah satu tonggak perekonomian masyarakat pesisir, dengan kemajuan ilmu pengetahuan dan teknologi model pengembangan pengelolaan wilayah pesisir dengan model ekowisata dimana sangat memperhatikan keberlangsungan dan kelestarian dari suatu potensi yang ada, (Yulisa et al. 2016). Ekowisata tidak hanya menekankan pada perekonomian saja, melainkan pada unsur pendidikan dan dukungan usaha konservasi disuatu wilayah. Ekowisata mulai mengarah pada pelestarian lingkungan dan ekologis yang sering disebut dengan ekowisata di era globalisasi ini. Sehingga perlu digali dan dikembangkan guna menjadikan wisatawan sadar dan peduli akan lingkungan (Kementerian Kebudayaan dan Pariwisata Indonesia, 2002). Penerapan model ekowisata pada pulau-pulau kecil yang dimiliki Kabupaten Bintan sendiri sangat diperlukan, salah satu pulau yang belum di kelola yaitu Pulau Soreh (P. Soreh).

Pulau Soreh merupakan salah satu pulau yang berada di Desa Pangkil, Kecamatan Teluk Bintan, Kabupaten Bintan dengan batas wilayah Utara Desa Pengujan, Selatan Kota Batam, Barat Kota Batam, dan Timur Kota Tanjungpinang. P. Soreh termasuk pulau yang tak berpenghuni menyimpan potensi ekologis yang belum banyak diketahui secara publik. Potensi ekologis yang ada pada perairan P. Soreh dapat dikembangkan menjadi pengelolaan pulau-pulau kecil dengan sistem ekowisata untuk diving. P. Soreh diduga memiliki kondisi ekosistem terumbu karang yang masih sangat baik, dikarenakan belum adanya aktivitas masyarakat seperti industri, pembangunan, dan pemukiman yang akan mempengaruhi perairan dan kehidupan biota disekitarnya. Dengan demikian, perlu dilakukan penelitian mengenai analisis kesesuaian pada kawasan terumbu karang di Perairan P. Soreh, Kabupaten Bintan untuk ekowisata diving. Tujuan penelitian ini adalah untuk mengetahui potensi ekologis serta analisis kesesuaian dan daya dukung kawasan perairan Pulau Soreh untuk ekowisata diving.

\section{MATERI DAN METODE}

\section{Waktu dan Tempat}

Penelitian ini dilaksanakan pada Bulan Oktober hingga Desember 2021, lokasi penelitian di Perairan Pulau (P). Soreh. Peta lokasi penelitian disajikan pada pada Gambar 1.

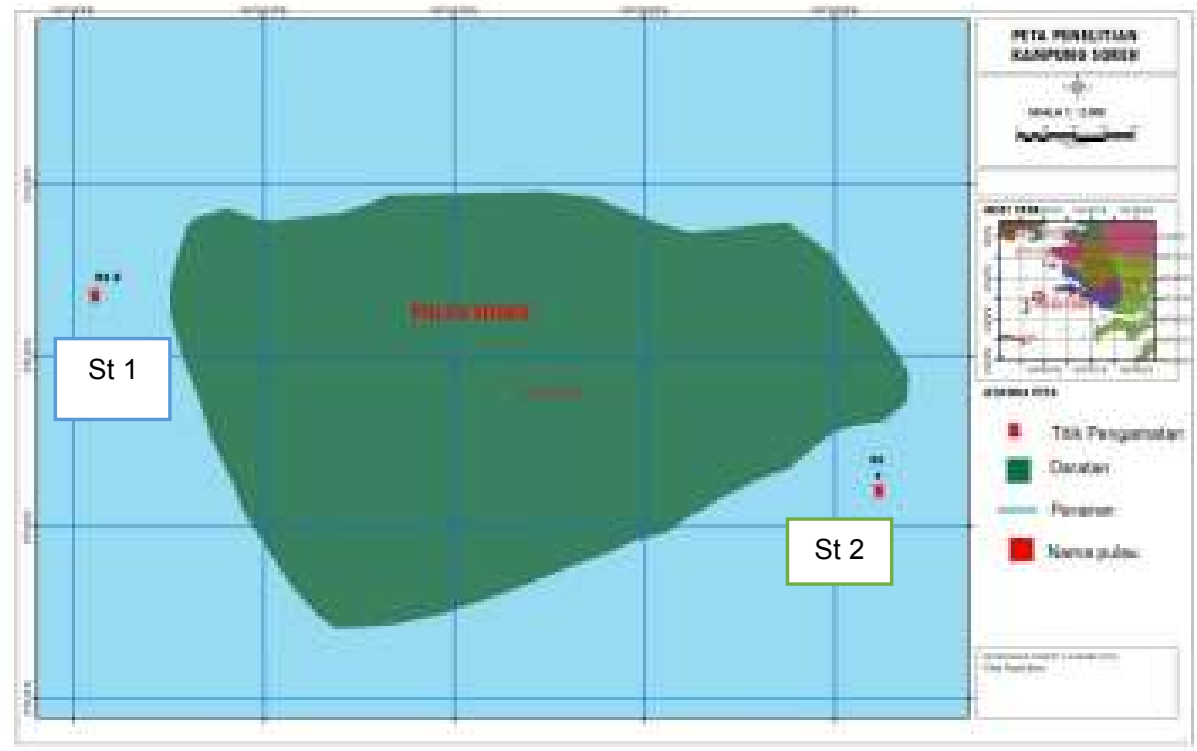

Gambar 1. Peta lokasi penelitian

To Cite this Paper: Ramlan, M., Kurniawan, D., Susiana. 2021. Analisis Kesesuaian Kawasan Perairan untuk Ekowisata Diving di Pulau Soreh, Kabupaten Bintan. Samakia: Jurnal IImu Perikanan, 12 (2) : 131-138

Journal Homepage: https://journal.ibrahimy.ac.id/index.php/JSAPI 


\section{Alat dan Bahan}

Alat yang digunakan dalam penelitian analisis kesesuaian kawasan perairan untuk ekowisata snorkeling dan diving di P. Soreh, Kabupaten Bintan yaitu alat selam, kamera bawah air, GPS, secchi disc, bandul besi, meteran, dan alat tulis. Sedangkan bahan yang diperlukan yaitu tali rapia, buku tulis, dan buku identifikasi.

\section{Prosedur Penelitian}

pengumpulan data yang digunakan pada penelitian ini adalah metode survei yang dilakukan secara langsung di lapangan, kemudian dilakukan pengukuran dan pengumpulan informasi/data, selanjutnya data tersebut dianalisis dengan menggunakan program Microsoft Excel untuk dijadikan data primer yang disajikan secara deskriptif, sedangkan data sekunder merupakan data atau informasi pendukung dari buku, jurnal serta informasi/literatur dari berbagai instansi pemerintah dan masyarakat yang bersangkutan.

\section{Pengumpulan Data}

Pengumpulan data mengunakan metode PIT (Point Intersept Transek) untuk terumbu karang dan metode UVC (Underwater Visual Census) untuk pengambilan ikan karang, kesesuaian ekowisata diving berdasarkan perkalian skor dan bobot yang diperoleh dari setiap parameter. Parameter perairan yang diambil dari penelitian ini bisa dilihat pada Tabel 1.

Tabel 1. Matriks kesesuaian kawasan ekowisata diving.

\begin{tabular}{|c|c|c|c|c|}
\hline No. & Parameter & Bobot & Standar Parameter & Skor \\
\hline \multirow[t]{5}{*}{1.} & \multirow{5}{*}{ Tutupan Karang (\%) } & 5 & $>75$ & 3 \\
\hline & & & $50-75$ & 2 \\
\hline & & & $25-50$ & 1 \\
\hline & & & $<20$ & 0 \\
\hline & & & 100 & 3 \\
\hline \multirow[t]{4}{*}{2.} & \multirow[t]{4}{*}{ Kecerahan Perairan (\%) } & 5 & 100 & 3 \\
\hline & & & $50-<100$ & 2 \\
\hline & & & $20-50$ & 1 \\
\hline & & & $<20$ & 0 \\
\hline \multirow[t]{4}{*}{3.} & \multirow[t]{4}{*}{ Jumlah Jenis Life Form } & 3 & $>12$ & 3 \\
\hline & & & $7-12$ & 2 \\
\hline & & & $4-6$ & 1 \\
\hline & & & $<4$ & 0 \\
\hline \multirow[t]{4}{*}{4.} & \multirow{4}{*}{$\begin{array}{l}\text { Jumlah Jenis Ikan } \\
\text { Karang }\end{array}$} & 3 & $>50$ & 3 \\
\hline & & & $30-50$ & 2 \\
\hline & & & $10-30$ & 1 \\
\hline & & & $<10$ & 0 \\
\hline \multirow[t]{4}{*}{5.} & \multirow[t]{4}{*}{ Kecepatan Arus (cm/detik). } & 3 & $0-15$ & 3 \\
\hline & & & $15-30$ & 2 \\
\hline & & & $30-50$ & 1 \\
\hline & & & $>50$ & 0 \\
\hline \multirow[t]{4}{*}{6.} & \multirow{4}{*}{$\begin{array}{l}\text { Kedalaman } \\
\text { Karang. }\end{array}$} & 3 & $7-10$ & 3 \\
\hline & & & $5-7$ & 2 \\
\hline & & & $3-5$ & 1 \\
\hline & & & $1-3$ & 0 \\
\hline \multirow[t]{4}{*}{7.} & \multirow[t]{4}{*}{ Aksesibilitas } & 3 & 3 & 3 \\
\hline & & & 2 & 2 \\
\hline & & & 1 & 1 \\
\hline & & & 0 & 0 \\
\hline
\end{tabular}

To Cite this Paper: Ramlan, M., Kurniawan, D., Susiana. 2021. Analisis Kesesuaian Kawasan Perairan untuk Ekowisata Diving di Pulau Soreh, Kabupaten Bintan. Samakia: Jurnal IImu Perikanan, 12 (2) : 131-138

Journal Homepage: $\underline{\text { https://journal.ibrahimy.ac.id/index.php/JSAPI }}$ 


\begin{tabular}{ccccc}
\hline No. & Parameter & Bobot & Standar Parameter & Skor \\
\hline 8. & Biota Berbahaya & 1 & 0 & 3 \\
& & & 1 & 2 \\
& & & $2-3$ & 1 \\
\hline
\end{tabular}

Sumber: Modifikasi (Yulianda et al. 2010) dan Karnanda et al. (2019).

\section{Analisis Data}

Analisis indeks kawasan wisata dilakukan untuk mengetahui kelayakan dari suatu wilayah untuk dijadikan kawasan ekowisata dengan perhitungan rumus sebagai berikut:

$$
\mathrm{IKW}=\Sigma[\mathrm{ni} / \mathrm{Nmaks}] \times 100 \%
$$

Dimana :

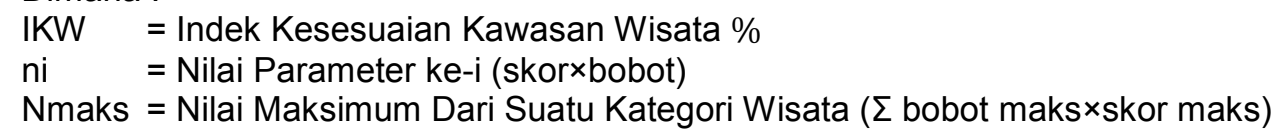

Keterangan indeks tingkat kesesuaian kawasan wisata sebagai berikut:

S1 = Sangat sesuai (IKW: $75-100 \%)$

S2 = Sesuai (IKW: $50-75 \%)$

S3 = Sesuai bersyarat (IKW: $25-50 \%)$

$\mathrm{N} \quad=$ Tidak sesuai $(\mathrm{IKW}:<25 \%)$

Penentuan kelas kesesuaian lahan untuk kategori tertentu dapat dilakukan dengan menghitung nilai interval kelas dari masing-masing nilai kesesuaian lahan ekowisata. Pembagian kelas kesesuaian ekowisata bahari mengacu pada (Yulianda et al. 2010) dibagi menjadi 4 (empat) kelas kesesuaian yaitu ; Sangat sesuai (S1) dengan IKW >75\%, Sesuai (S2) IKW 50-75\%, Sesuai bersyarat (SB) dengan IKW $<50 \%$, dan Tidak sesuai (TS) dengan IKW $<25 \%$.

Analisis daya dukung ekologi dimaksudkan untuk menganalisis tingkat maksimum penggunaan suatu ekosistem, berupa jumlah atau kegiatan yang di akomodasikan di dalamnya, sebelum terjadi suatu penurunan kualitas ekologis. DDK (Daya Dukung Kawasan) adalah jumlah maksimum pengunjung yang secara fisik dapat ditampung dikawasan yang disediakan pada waktu tertentu tanpa menimbulkan gangguan pada alam dan manusia, perhitungan DDK mengacu pada (Yulianda et al. 2010).

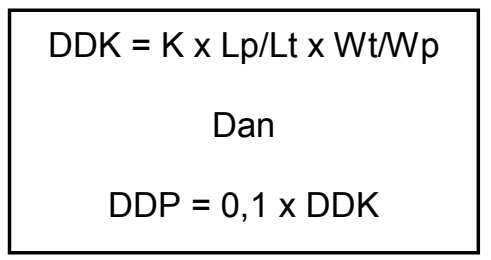

Keterangan :

DDK = Daya dukung kawasan (orang/area)

DDP = Daya dukung pemanfaatan (orang/area)

$\mathrm{K}=$ Kapasitas ekologi per satuan unit area $\left(\mathrm{m}^{2}\right)$

$\mathrm{Lp} \quad=$ Luas area yang dapat dimanfaatkan $\left(\mathrm{m}^{2}\right)$

Lt $\quad=$ Unit area untuk kategori snorkeling $500\left(\mathrm{~m}^{2}\right)$

$\mathrm{Wt} \quad=$ Waktu yang disediakan oleh kawasan untuk kegiatan wisata dalam 1 hari (jam)

$\mathrm{Wp} \quad=$ waktu yang dihabiskan oleh pengunjung untuk setiap kegiatan (jam) 


\section{HASIL DAN PEMBAHASAN}

Hasil dari penelitian kesesuaian kawasan perairan ekowisata diving, pada stasiun 1 didapatkan jumlah IKW 66,67\% dan pada stasiun 2 IKW berjumlah 60,25\%. Tabel indek kesesuaian kawasan ekowisata tiap stasiun bisa dilihat pada Tabel 2 dan 3, Sedangkan daya dukung kawasan untuk pemanfaatan kegiatan divingpada stasiun 1 berjumlah 175 orang/area serta pada stasiun 2 berjumlah 175 orang/area yang dapat dilihat pada Tabel 4 .

Tabel 2. Indeks Kesesuaian Kawasan Ekowisata Diving Stasiun 1.

\begin{tabular}{|c|c|c|c|c|c|}
\hline No & Parameter Stasiun 1 & Bobot & Nilai Parameter & Skor & $\mathrm{Ni}$ \\
\hline 1. & Tutupan Karang (\%) & 5 & 59 & 2 & 10 \\
\hline 2. & Kecerahan Perairan (\%) & 5 & 62,5 & 2 & 10 \\
\hline 3. & Jumlah Jenis Life Form & 3 & 7 & 2 & 6 \\
\hline 4. & Jumlah Jenis Ikan Karang & 3 & 13 & 1 & 3 \\
\hline 5. & Kecepatan Arus (cm/detik) & 3 & 10,82 & 3 & 9 \\
\hline 6. & Kedalaman Terumbu Karang (m) & 3 & 8 & 3 & 9 \\
\hline 7. & Aksesibilitas & 3 & 1 & 1 & 3 \\
\hline \multirow[t]{2}{*}{8.} & Biota Berbahaya & 1 & 1 & 2 & 2 \\
\hline & & $\underset{\substack{\mathrm{Ni} \\
\text { N maks } \\
\text { IKW }}}{c}$ & & & $\begin{array}{c}52 \\
78 \\
66,67 \%\end{array}$ \\
\hline
\end{tabular}

Tabel 3. Indeks Kesesuaian Kawasan Ekowisata Diving Stasiun 2.

\begin{tabular}{llcccc}
\hline No & \multicolumn{1}{c}{ Parameter Stasiun 2 } & Bobot & Nilai Parameter & Skor & Ni \\
\hline 1. & Tutupan Karang (\%) & 5 & 70 & 2 & 10 \\
2. & Kecerahan Perairan (\%) & 5 & 47,2 & 1 & 5 \\
3. & Jumlah Jenis Life Form & 3 & 8 & 1 & 3 \\
4. & Jumlah Jenis Ikan Karang & 3 & 14 & 1 & 3 \\
5. & Kecepatan Arus (cm/detik) & 3 & 13,36 & 3 & 9 \\
6. & Kedalaman Terumbu Karang (m) & 3 & 8 & 3 & 9 \\
7. & Aksesibilitas & 3 & 1 & 1 & 3 \\
8. & Biota Berbahaya & 1 & 1 & 2 & 2 \\
& & & & & \\
& & Ni & & & $\mathbf{4 7}$ \\
& & $\mathbf{N ~ m a k s}$ & & $\mathbf{6 0 , 2 5} \%$ \\
& IKW & & & \\
& & & & & \\
\end{tabular}

Tabel 4. Daya Dukung Kawasan Ekowisata Diving

\begin{tabular}{llccc}
\hline No & Stasiun dan Titik Pengamatn & $\begin{array}{l}\text { Daya } \\
\text { Kawasan } \\
\text { (Orang/Area) }\end{array}$ & Dukung & $\begin{array}{l}\text { Daya Dukung } \\
\text { Pemanfaatan } \\
\text { (Orang /Area) }\end{array}$ \\
\hline 1. & St1 & 1.754 & 175 & 175 \\
2. & St2 & 1.754 & 175 & \\
\hline
\end{tabular}

Tutupan karang yang dijumpai pada perairan P. Soreh terdiri dari 4 bentuk tutupan karang yaitu karang hidup, abiotik, algae, dan others, setiap stasiun pada titik pengamatan memiliki perbedaan jumlah tutupan karang yang dijumpai. Berdasarkan keberadaan karang yang dijumpai, yaitu

To Cite this Paper: Ramlan, M., Kurniawan, D., Susiana. 2021. Analisis Kesesuaian Kawasan Perairan untuk Ekowisata Diving di Pulau Soreh, Kabupaten Bintan. Samakia: Jurnal IImu Perikanan, 12 (2) : 131-138

Journal Homepage: https://journal.ibrahimy.ac.id/index.php/JSAPI 
terletak pada karang miring (reef slope), Persen tutupan karang hidup untuk stasiun 1 sebesar $59 \%$ dengan kondisi tutupan karang baik, berdasarkan matriks kesesuaian ekowisata diving tutupan karang stasiun 1 termasuk dalam kategori S2 (sesuai). Persen tutupan karang hidup untuk stasiun 2 sebesar $70 \%$ dengan kondisi tutupan karang baik, berdasarkan matriks kesesuian ekowisata diving tutupan karang termasuk dalam kategori S2 (sesuai). Menurut Widhianingrum et al. (2013) terumbu karang memiliki daya tarik yang tinggi untuk dijadikan lokasi wisata, karena memiliki keanekaragaman yang unik dan indah. Semakin tinggi persentase tutupan karang hidup di suatu perairan maka semakin besar tingkat produktifitas dan aktifitas biota di sekitar karang tersebut sehingga terumbu karang dapat dimanfaatkan sebagai objek wisata bahari karena memiliki nilai estetika yang tinggi, Karang dapat tumbuh dan berkembang pada lingkungan yang sesuai dengan kebutuhanya, Munua et al. (2019).

Data kecerahan diambil saat air pasang atau naik dengan kedalaman yang berbeda-beda di setiap stasiunya, sedangkan stasiun 1 dan stasiun 2 memiliki tingkat kecerahan $62,5 \%$ dan $47,2 \%$, berdarsarkan data tersebut matriks kesesuaian untuk ekowisata diving di Perairan P. Soreh terkategorikan S2 (sesuai). Chasanah et al. (2017) menyatakan, bahwa selain menjadi parameter kualitas air, kecerahan juga menjadi parameter dalam kesesuaian wisata yaitu untuk menjadi parameteryangmencirikannilaikeindahanpemandangansaatmelakukankegiatan berwisata.

Stasiun 1 memiliki 7 life form yang terdiri dari Acropora digitata (ACD), Acropora encrusting (ACE), Coral foliose (CF), Coral encrusting (CE), Coral masroom (CMR), Coral sub massive (CS), dan Coral branching (CB) didominasi Coral foliose (CF). Pada stasiun 2 memilki 8 life form yang terdiri dari Acropora digitata (ACD), Acropora sub massive (ACS), Acropora encrusting (ACE), Coral sub massive (CS), Coral massive (CM), Coral foliose (CF),dan Coral masroom (CMR) didominasi oleh Coral sub massive (CS). Menurut Pasak et al.(2017) dalam kegiatan ekowisata diving jenis life form karang sangat dibutuhkan sebagai variasi yang dapat dinikmati di bawah laut, jumlah jenis life form karang juga menentukan baik dan buruknya keadaan karang yang ada.

Keberadaan ikan karang yang dijumpai pada perairan P. Soreh tidak terlalu banyak, hanya 15 jenis ikan karang yang di temukan secara keseluruhan diantara stasiun 1 dengan stasiun 2, pada stasiun 1 didapatkan 13 jenis ikan karang, pada stasiun 2 didapatkan 14 jenis ikan karang. Berdasarkan matriks indek kesesuaian kawasan wisata menunjukkan bahwa keberadan ikan karang pada perairan $\mathrm{P}$. Soreh, untuk stasiun 1 dan stasiun 2 berdasarkan indeks kesesuaian wisata terkategorikan S3 (Sesuai bersyarat) untuk dilakukan ekowisata diving. Menurut Widhianingrum et al. (2013) keberadaan ikan karang sangat tergantung pada kerapatan dan kepadatan dari tutupan karang hidup serta life form karang yang ada. Minimnya jenis ikan karang yang dijumpai dari setiap stasiun yang ada bisa disebabkan oleh kurangnya kerapatan dan kepadatan life form karang yang ada.

Kecepatan arus di stasiun 1 dan stasiun 2 masih tergolong rendah di karenakan pengambilan sampel berada di belakang dan samping $\mathrm{P}$. Soreh yang tidak terkena hembusan angin utara, sebagaimana posisi pada depan P. Soreh yang langsung berhadapan dengan arah utara. Hal ini sesuai dengan pernyataan Karnanda et al. (2019), bahwa pantai yang terlindung dari hembusan angin yang terhalang oleh keberadaan pulau dapat mempengaruhi arus yang ada. Habibi et al. (2017), juga menyatakan hal yang sama bahwa arus yang tidak kencang dan tenang memberikan rasa nyaman untuk aktivitas wisata pantai lainnya, hal ini menunjukan bahwa kecepatan arus di $P$. Soreh masuk pada kategori S1 (sangat sesuai) untuk kegiatan ekowisatadiving.

Kedalaman perairan untuk lokasi diving tidak jauh berbeda dari setiap stasiunnya, untuk stasiun 1 dan stasiun 2 data parameter kedalaman di ambil saat air naik atau pasang yang berada di karang miring (reef slope), dari data stasiun 1 dan stasiun 2 terkategorikan S1 (Sangat Sesuai) untuk aktivitas ekowisata diving di P. Soreh. Terumbu karang tumbuh pada kedalaman 1 - 10 $\mathrm{m}$,kedalaman terumbu karang merupakan salah satu faktor untuk menikmati keindahan yang ada pada ekologis terumbu karang tersebut, (Tuwo et al. 2009).

Menurut Wanda \& Pangestuti (2018), akses jalan raya, ketersediaan sarana transportasi dan rambu-rambu penunjuk jalan merupakan aspek penting bagi sebuah destinasi. Apabila ketiga aspek tersebut terpenuhi maka destinasi tersebut sesuai untuk dijadikan destinasi wisata. Berdasarkan hasil analisis aksesibilitas P. Soreh adalah memenuhi 1 aspek atau ketentuan tersebut yang terkategori sesuai bersyarat (S3) untuk dijadikan kawasan ekowisata snorkeling dan

To Cite this Paper: Ramlan, M., Kurniawan, D., Susiana. 2021. Analisis Kesesuaian Kawasan Perairan untuk Ekowisata Diving di Pulau Soreh, Kabupaten Bintan. Samakia: Jurnal IImu Perikanan, 12 (2) : 131-138

Journal Homepage: https://journal.ibrahimy.ac.id/index.php/JSAPI 
diving dengan adanya transportasi yang bisa digunakan untuk menuju P. Soreh yaitu dengan menggunakan transportasi dari pelabuhan Tanjung Siambang dan bisa juga transportasi dari Pelantar 2 Kota Tanjungpinang.

Biota berbahaya merupakan komponen yang dapat mengganggu aktivitas ekowisata diving.Berdasarkan hasil survey dilapangan pada saat melakukan penyelaman di Perairan P. Soreh hanya satu jenis biota berahaya yang di temukan pada setiap stasiun dan titik pengamatan yang ada yaitu jenis biota Diadema setosum atau dalam bahasa lokalnya sering disebut bulu babi, landak laut, dan bulu mata.

\section{KESIMPULAN}

1. Berdasarkan potensi ekologis dari setiap stasiun pengamatan dapat disimpulkan bahwa kawasan perairan P. Soreh berpotensi untuk dilakukannya kegiatan ekowisata diving.

2. Berdasarkan analisis dan tingkat daya dukung untuk pemanfaatan kegiatan ekowisata diving di Perairan P. Soreh berada pada kategori S2 (sesuai), dengan tingkat daya dukung sebesar 3.508 orang/area untuk kegiatan diving

\section{DAFTAR PUSTAKA}

BPS Provinsi Kepulauan Riau. 2015. Kepulauan Riau Dalam Angka 2015. Badan Pusat Statistik Provinsi Kepulauan Riau. Tanjungpinang. 455 hal.

Candri, D. A., Ahyadi, H., Riandinata, S. K., Virgota, A. 2019. Analisis Persentase Tutupan Terumbu Karang Gili Tangkong, Sekotong Kabupaten Lombok Barat. Jurnal IImiah IImu Biologi. 5(1): 29-35.

Chasanah,I.,Purnomo,P.W.,Haeruddin.2017.AnalisisKesesuaianWisataPantai Jodo Desa Sidorejo Kecamatan Gringsing Kabupaten Batang. Jurnal Pengelolaan Sumberdaya Alam dan Lingkungan. 7 (3) :235-243.

Juliana., Sya'rani, L., Zainuri, M. 2013. Kesesuaian dan Daya Dukung Wisata Bahari di Perairan Bandengan Kabupaten Jepara Jawa Tengah. Jurnal Perikanan dan Kelautan Tropis. 9 (1) : $1-7$.

Karnanda, Lestari, F., \& Kurniawan, D. (2019). Analisis Kesesuaian Kawasan Perairan Pulau Bungin untuk Ekowisata Snorkeling di Kecamatan Tambelan Kabupaten Bintan. Jurnal Pengelolaan Perairan, 2(1):1-10.

Keputusan Menteri Lingkungan Hidup No. 4 2004.Penilaian Kondisi TerumbuKarang.Menteri Lingkungan Hidup. Jakarta.

Keputusan Menteri Lingkungan Hidup No. 51 .2004. Baku Mutu Air Untuk Biota.Menteri Lingkungan Hidup. Jakarta.

Kantona, I., Adi, W., Kurniawan. 2016. Potensi Kesesuaian Lokasi Wisata Selam Permukaan (Snorkeling) Sebagai Pengembangan Wisata Bahari Pantai Turun Abang Kabupaten Bangka. Akuatik- Jurnal Sumberdaya Perairan. 10(2): 22-29.

Koroy, K., Yulianda, F., Butet, N.A. 2017. Pengembangan Ekowisata Bahari Berbasis Sumberdaya Pulau-Pulau Kecil Di Pulau Sayafi Dan Liwo, Kabupaten Halmahera Tengah. Jurnal Teknologi Perikanan dan Kelautan: 8(1).

Munua, R., Hamuna, B., Kalor. D. J. 2019. Tutupan Terumbu Karang di Perairan Teluk Tanah Merah, Kabupaten Jayapura. Jurnal Ilmu Kelautan dan Perikanan Papua. 2(1) : 30-36. 
Perdana, I.B., Suasti, Y., Ahyuni. 2016. Identifikasi Potensi Fisik Pesisir Pantai Wisata Bahari Kelurahan Teluk Kabung Selatan Kecamatan Bungus Teluk Kabung Kota Padang. Jurnal Of Geografik. 5 (2) : 123-130.

Pasak, H.A., Manapa, E.S., Ukkas, M. 2017. Studi Pengembangan Ekowisata Bahari Di Pulau Pasir Putih Kabupaten Polewali Mandar. Spermonde. 3 (1) : 29-34.

Rumahorbo, B. T., Hamuna, B., Dimara, L. 2019. Kondisi Ekosistem Terumbu Karang di Perairan Tablasupa Kabupaten Jayapura dan Nilai Manfaat Ekonominya. Jurnal Ilmu Kelautan dan Perikanan Papua. 1(2): 58-63.

Rizal, S., Pratomo, A., Irawan, H. 2016. Tingkat Tutupan Ekosistem Terumbu Karang Di Perairan Pulau Terkulai. Jurnal Ilmu Kelautan Universitas Maritim Raja Ali Haji: Tanjungpinang, Kepulauan Riau.

Rohman, F., Ghofar, A., Saputra, S.W. 2016. Partisipasi Masyarakat Dalam Pengembangan Kawasan Ekowisata Di Desa Bedono Kecamatan Sayung Kabupaten Demak. Jurnal Manajemen Sumberdaya Perairan. 5 (2) : 61-69.

Saraswati, N.L.G.R.A., Yulius., Rustam, A., Salim, H.L., Heriati, A., Mustikasari, E. 2017. Kajian Kualitas Air untuk Wisata Bahari di Pesisir Kecamatan Moyo Hilir dan Kecamatan Lape Kabupaten Sumbawa. Jurnal Segara. 13 (1) : 37-47.

Sugiyono.2005. Statistika Untuk Penelitian. Penerbit. Alfabeta. Bandung.306 hlm. 2008. Metode Penelitian Kuantitatif, Kualitatif dan R \& D. Alfabeta. Bandung. 295 halaman.

Tuwo, A., Tresnati, J., Parawansa, S.B. 2009. Analisis Kelayakan Pengembangan Ekowisata Diving dan Snorkeling di Kepulauan Tanakeke. Jurnal Sains dan Teknologi, 9 (2) : 157-164.

Widhianingrum,I.,Indarjo,A.,Pratikto,I.2013.StudiKesesuaianPerairanUntuk Ekowisata Diving Dan Snorkeling Di Perairan Pulau Keramat, Kebupaten Sumbawa Provinsi Nusa Tenggara Barat. Journal Of Marine Research. 2 (3) : 181-189.

Wanda,I.B.K.,Pangestuti,E.2018.PengaruhPengembanganKomponenDestinasi Wisata terhadap Kepuasan Pengunjung (Survei pada Pengunjung Situs Trowulan). Jurnal Adnministrasi Bisnis (JAB). 55 (3) :83-91.

Yulianda, F., 2007. Ekowisata Bahari Sebagai Alternatif Pemanfaatan Sumberdaya Pesisir Berbasis Konservasi. Makalah Seminar Sains Pada Departemen Manajemen Sumberdaya Perairan. Fakultas Perikanan dan IImu Kelautan IPB. Bogor.

Yulianda, F, Fachrudin A, Hutabarat AA, Hartati S, Kusharjani, Ho, SK. 2010. Pengelolaan pesisir dan laut secara terpadu. (integrated coastal and marine managemant) School of Enviromental Conservation and ecotourism Managemant (SECEM). Jakarta. (ID): Ministry of Forestry Republic of Indonesia. KONICA. Korea International Cooperation Agency.

Yulisa, E.N., Johan. Y., Hartono, D. 2016. Analisis Kesesuaian Dan Daya Dukung Ekowisata Pantai Kategori Rekreasi Pantai Laguna Desa Merpas Kabupaten Kaur. Jurnal Enggano: 97-111. 